\title{
The Discourse of Cutting: A Study of Visual Representations of Self-Injury on the Internet
}

\author{
Hans T. Sternudd
}

\begin{abstract}
In this paper some results from a study of over 6000 photographs of self-inflicted injuries is presented. The typical image is taken by somebody that presents themselves as females; it depicts a body part: an arm which has been cut. Seldom contextualised content is represented. Analyses from a traditional feminists perspective is likely to produce an interpretation that these images shows feminine bodies victimized under a patriarchal oppression. But here an alternative interpretation that focus on the fact that the few contextualised features makes identifications possible for many people regardless of sex, culture, class, race etc. The images emphasize the body and the wound, entities that 'everybody' can relate to. We should also consider the aggressive character of the act of cutting. Therefore an alternative interpretation is suggested that emphasize cutting as an act of resistance from a position that's not necessary based on traditional gender formations. The place for this struggle is the skin and the paper concludes with a suggestion that skin is not only the place for cutting but also the actual place for discursive closure and establishing of identity.
\end{abstract}

Key Words: Self-injury, cutting, skin, skin ego, Internet, gender, discourse.

$* * * * *$

In this paper I argue for the notion that skin cutting is a way of making sense to pain. ${ }^{1}$ The line of argumentation is based on the understanding of self-injury, especially the practice of cutting, as a language that talks about an inner pain that's obscured. I propose that the visual aspect is crucial for many self-injurers as it transforms something unspeakable to something concrete and visual (as a bleeding wound or a scar). If that's true analyses of images of cutting can give us knowledge of the mechanism behind self-injury that we can't derive from other sources.

Cutting alludes to a practice that's deployed by a group of people, mostly young who commonly are referred to as self-injurers or self-harmers. A self-injurer is usually defined, after the American psychiatrist Armando R Favazza, as someone who repeatedly has inflicted superficial injuries or mutilations to herself without suicidal intentions. ${ }^{2}$ A self-injurer is also said to have difficulties to resist the impulse to harm her. The act is often understood as a response to an increasing feeling of inner tension which is brought to an end by the injury. ${ }^{3}$

In this presentation I won't make an excessive use of terminology utilized in discursive theory. But for the record I use discourse in two different ways. Discourse is used on one hand as meaning production produced in a field, a 
discourse order, that's created with and around the practice of cutting; and on the other hand, in a more symbolic way, as the way meaning is produced by the cutting itself. In the latter definition cutting becomes a speech act produced on the skin by penetration.

Images of self-injury have to my knowledge not been the subject for any academic studies. In studies on for instance Internet communities or other forums for self-injurers, you'll find commentaries which express concerns about the spreading of material, like photo, video and artwork with representations of selfinjury. ${ }^{4}$ This kind of material is commonly understood as triggering, a notion that's, at least officially, shared by most sites and communities devoted to questions about self-injury. Visitors are warned before they are exposed to images and it is often forbidden to publish or link to images on forums. Scholars never seem to feel the need to base there assumptions of the danger of images of selfinjuries on any studies, it seem to be so obvious that it's unquestionable. One of the purposes of my research has been to problematise these presumptions by taking a closer look on the images of self-injury, the production and consumption of them. ${ }^{5}$

I focus on the type of self-injury that manifests itself as skin cutting. There are two reasons for this: Cutting is, according to studies, the most common technique of injuring ${ }^{6}$ and that it is a visual practice, both during the activity and afterwards when scars has become an index of something that has happened.

The images in this study are taken from a website, an Internet community dedicated to information about self-injury and support to self-injurers. Member of the community describe themselves, almost without exceptions, as having personal experience of self-injury. On this site it is possible contribute with autobiographical material like personal stories, poems and pictures/photos which are public accessible. More then 6000 photos has been uploaded. I have analysed the photos regarding their representational and formal aspects.

Not surprisingly were producers that could be referred to as female dominating. This is in line with prevalence in most studies of self-injury, and when also considering the fact that girls are more active in social communities on Internet and more often contribute with material like images, this result could be expected. ${ }^{7}$

Images of bodies or more precise body parts are dominating in the material; most common is arms, followed by legs. Close ups, only showing skin, is one of the largest categories. The method of inflicting the injury that's dominating the material is cutting, more then nine out of ten of the wounds seem to be done with razor blades, knifes or other sharp objects.

Let's take a look at some typical, representative images in my study. The first image we consider (fig 1) is an example of the statistical most frequent representation of cutting. ${ }^{8}$ It is taken by a female, it shows an arm with scars and it's lacking contextualized features.

In the discourse constituted of self-injurers you'll often find expressions of a wish to be for real, to be authentic. ${ }^{9}$ These images could be understood as way of 
expressing something true, as documentations of something real. How is then truth constructed in these images? Photography that is produced as indexical traces of light has in it self a capacity to produce contextualised truth.

Formal qualities can also be part of production of texts that's perceived as truthfully. According to a theory on how truth is made in images the Dutch socio semioticians Kress \& van Leeuwen suggests that we should consider both formal aspects like; colour saturation, differentiations and modulations; illumination and light, as well as representative aspects like contextualisation or not, if the image is abstract or have richness in details etc. Configurations of these create coding orientations that are producing truth in different discourses. ${ }^{10}$

Returning to fig. 1 and applying Kress \& van Leeuwens model we see that although the colour saturation is quite rich (it's far from being black and white) the differentiation is quite low; and that goes for the contrast and the variation of light as well. The image is blurry and without many details, it's lacking contextualisation. Taken together we see an image that's quite abstract, reduced on details and modulations. Kress \& van Leeuwen suggest that this modality could be labelled as an abstract coding orientation which has 'reduced the individual to the general and the concrete to its essential qualities'. ${ }^{11}$ They argue that this kind of images is typical for high art, and academic or scientific discourses. Hardly the ones you associate with self-injury. It can also be seen as a paradox that an activity understood as very private and egocentric is communicating with a visual expression that's reducing the individual.

Bodies inscribed in a visual field without contextualisation and with no depicting of depth or perspective are bodies without the possibility to act, which requires a third dimension. Laura Mulvey, professor in film and media studies, has suggested that representations like this are objectifying the depicted. ${ }^{12}$ The Swedish semiotician Anders Marner proposes that a reason to isolate an element in an image from its environment, like this, could be to give it a more generalized meaning. ${ }^{13}$ In the images of cutting these two characteristics is often present - they are objectifying and generalizing. Further more they show fragmentised bodies like in a symbolic cut-up. This way of representing bodies, and especially female bodies, is according to feminist art historians common in art practices (especially in modernist art), in advertising and fashion photographs. A body in parts is becoming an object, without the power of an organic whole body (which represents a subject with the possibility to act). The English art historian Griselda Pollock states that we are so used to view representations of cut-upped female bodies that the cut-up itself has become a sign for femininity and therefore of subordination. ${ }^{14}$

Extreme close-ups, in which skin tissue is filling up the whole picture, are a special category of image in the collection (fig. 2). These images are lacking information not only of a room that surrounds the body, but also which part of the body the skin belongs to. The body becomes totally decontextualized in the closeups, the lack of markers of context like gender, class or culture creates a body 
that's wiped out all other intersectional positions apart from being a body that has been cut, that belongs to a cutter. This lack of context gives in the close-ups rich opportunities of identification - everybody has a body, and has been wounded sometimes.

In the history of the western world men and women have been associated with formal qualities: woman has been characterized as shapeless and chaotic, unlike men that represent form and structure. The gender order is clear in conceptions of straight and sharp geometrical forms as more masculine than the feminine rounded and organic forms. If we apply this notion on fig. 1 we see how the arm, with its soft roundness represent something feminine, while the carved sharp lines creates a masculine structure. This interpretation could be verified by the understanding that cutting is a strategy to re-establish control. ${ }^{15}$ From a gender perspective the interpretation could be formulated like this: In the image we see how the feminine flesh is disciplined by the sharp instrument of masculinity. Even clearer seems this to us when we consider the images where blood is pouring out of the wounds (fig. 3 ). Through the more or less straight cut blood, an organic chaotic form element pours out. The bad blood is let out, leaving a structured entity on the skin. The scars become a sign for the re-establishing of order.

The interpretation that has been suggested so far is very much based on 'classical' feminist theories derived from the academic fields of art history and film theory. The problem with this approach is that it seems to recreate the female position as a victim. From a discursive perspective we know that the way we talk about the world is creating it and therefore we could ask for alternative ways of interpretations.

The amount of scars varies a lot between the images. When the number of cuts/scars becomes big enough a criss-cross pattern sometimes is created (fig. 4). This pattern could resemble the structure of a woven textile. When cutting has been going on for a long time scars tissues can create a thicker skin (so called keloid, fig. 5.). Symbolically this skin re-figuration could be seen as the creation of 'another layer to the body - a 'second skin". ${ }^{16}$ This can help us to see the cutting as an act of protection or resistance. An act directed against the interventions of the world. Cutting is separating the body from the body of others. Self-destructive act is often seen as repulsive and it pushes people away - they produce thereby a social isolation. $^{17}$

This deviant character of the act of cutting is one important feature to consider. Cutting isn't accepted in most discourses and the activity is by the executor often regarded as something shameful, and can therefore be a strategy to withdraw from situations that's unbearable. Too deliberately cut and thereby often permanently disfigure the skin is also a very strong rejection of the hegemonic ideals of beauty (especially for young women). With these examples I suggest a reinterpretation of cutting along the line of understanding cutting as an act of resistance instead of 
victimization. By giving actorship to the cutter we instead of a passive object create an active subject in

I understand cutting as a communicative act, not at least a communication with the acting subject as recipient. Understood as an act of formulating and thereby making sense of a indescribable 'inner' emotion the cutting could be regarded as a text that concretise feelings which makes them more bearable.

If so, what is then the message that cutting communicates? This is a question that's not so easy to answer, and can often be puzzling to cutters themselves. But if we look at cutting that takes the form of words, a category of cutting in which the communicative aspect is specially manifest, we see that anger is the feeling most frequent. In the material we find FUCK OFF, I HATE U/ME and other expressions of anger cut into the skin in $25 \%$ of all of the images with words, followed by disgust often directed against them selves (16\%). Anger is not the expression of a passive victim; it comes from somebody that is putting up a fight. Saying FTW!

Elaine Scarry has said that pain is something encapsulated and introvert - not just hard to speak about, but actually destroying language and replacing it with unarticulated groans and screams. ${ }^{18}$ I see cutting as an act that contradicts Scarry's notion. Skin becomes there a surface for inscription in wounds and blood that gives pain a shape and makes it possible to handle (at least for a moment). The fact that the substance, the ground of the text is based on a basic, humanly shared experience - being in a body that feels pain and are wounded, cutting has maybe a possibility to bridge over other differences. On the internet the network of cutters is based on this conception of a shared experience.

In the material for my study there's no difference between images produced by females or males, and there's few contextualizing elements in them. We can say that they only communicate through and with the skin. The skin becomes the arena on which discourse is formulated.

Inspired by psychoanalytic theories by Anzieu and Rösing ${ }^{19}$ I propose that the skin actually is the place where identity (at least symbolically) is constituted. Identity is here understood as a discursive formation in/on the skin where understanding of experiences from under it, from the inside, and from the outside is made sense of. This challenges notions that identity is something that comes from inside as well as the notions that identity is wrote upon the skin from outside.

As a consequence of this gender differences isn't important any longer; men, women and other gender formations all has the possession of skin in common. That's why we could see the skin ego as a third position that unites people and creates a new location for closure, for making meaning to the world. By cutting in the skin a connection between the two identity shaping 'worlds' is established and the cuts becomes in fact the text, a discursive closure that challenges other discourses on the field. I call this The discourse of cutting. 


\section{Images}

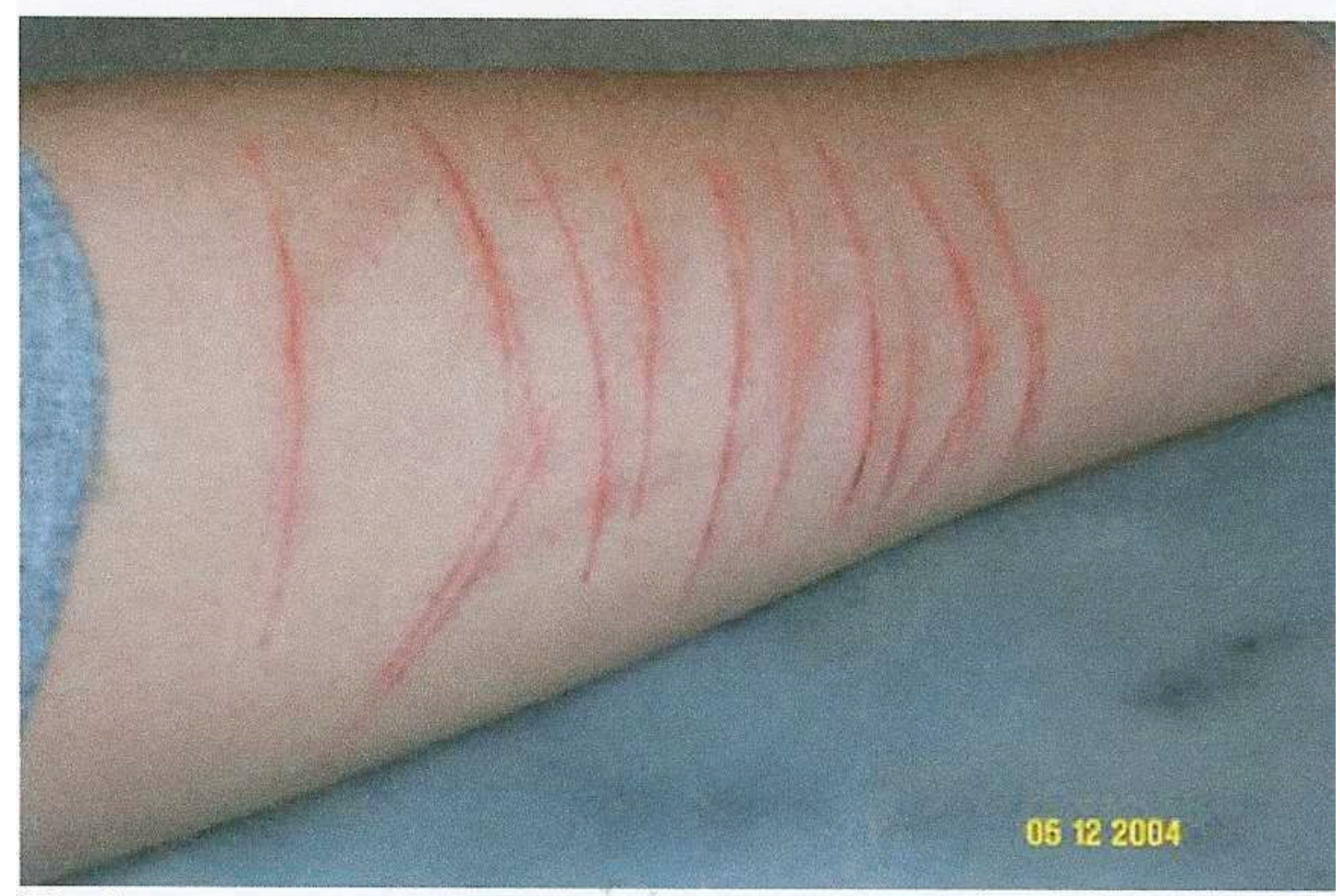

Fig. 1. 


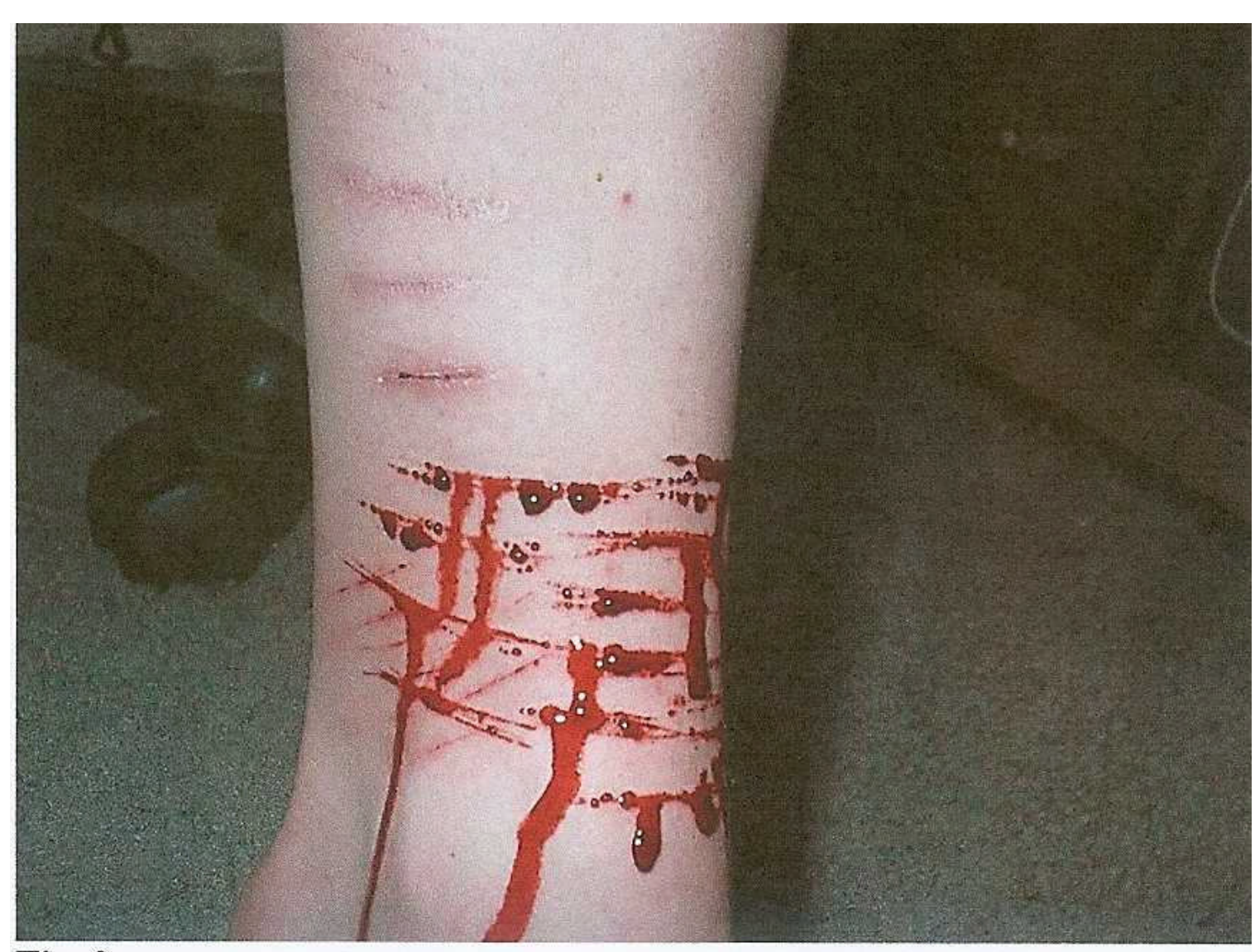

Fig. 2

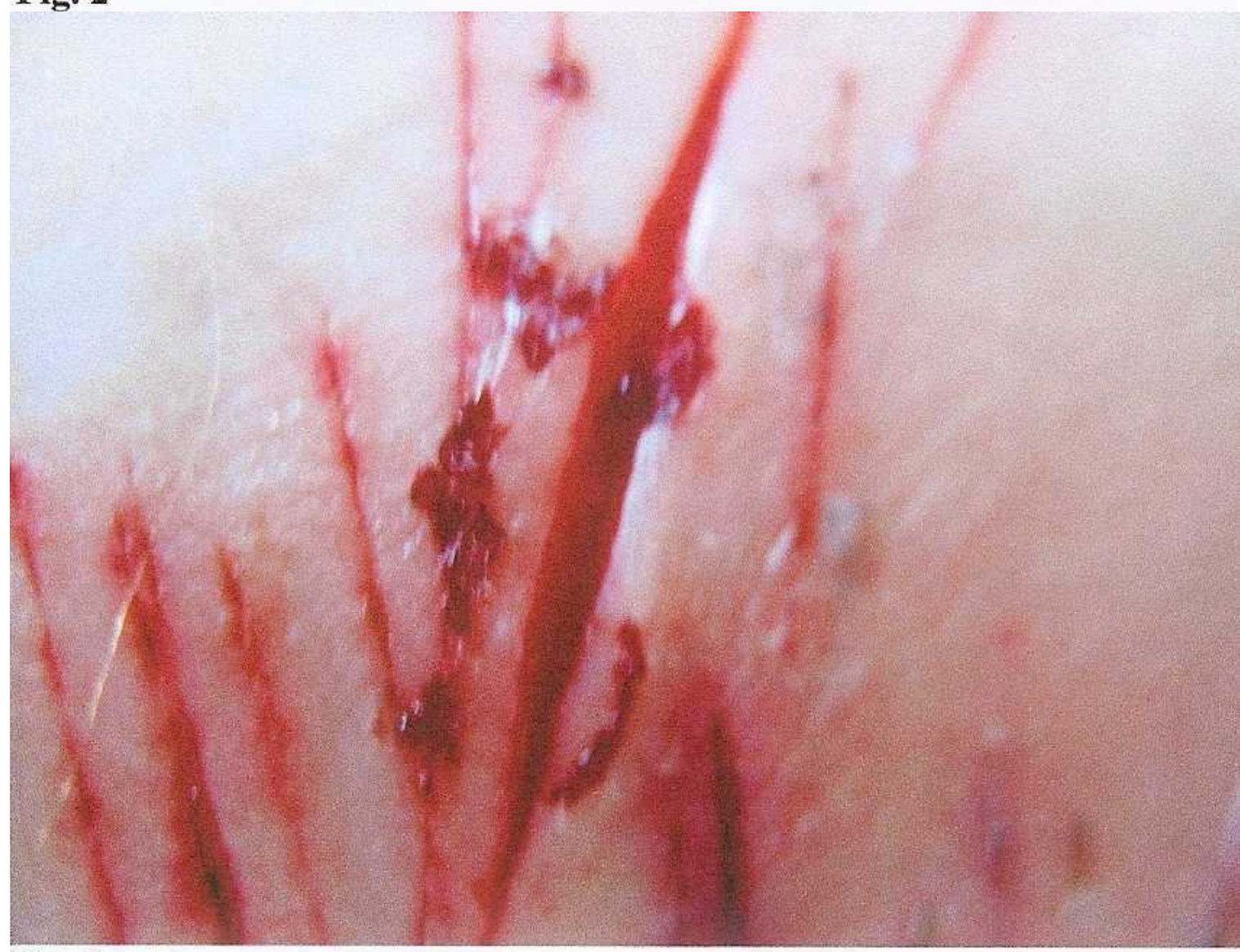

Fig. 3. 


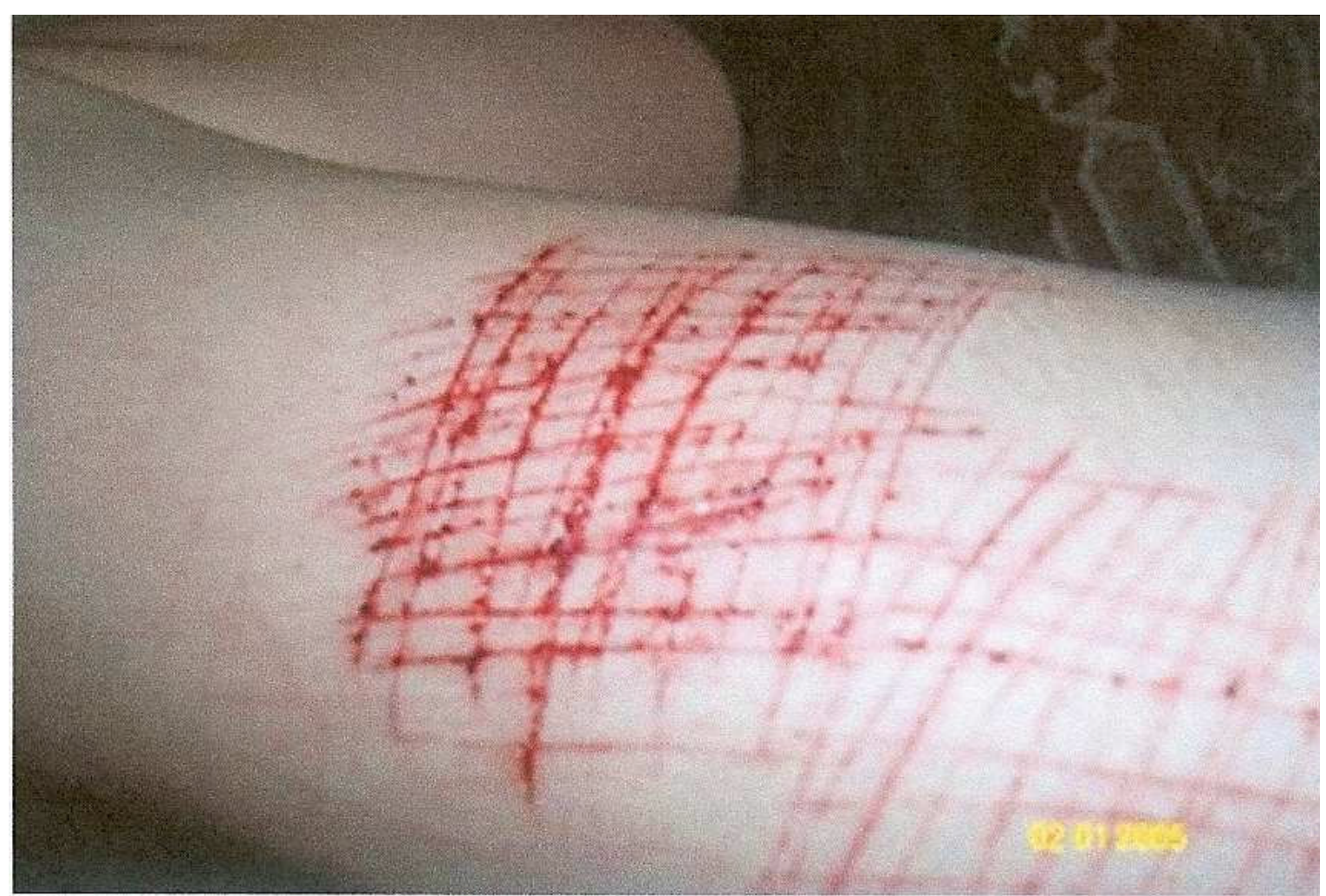

Fig. 4.

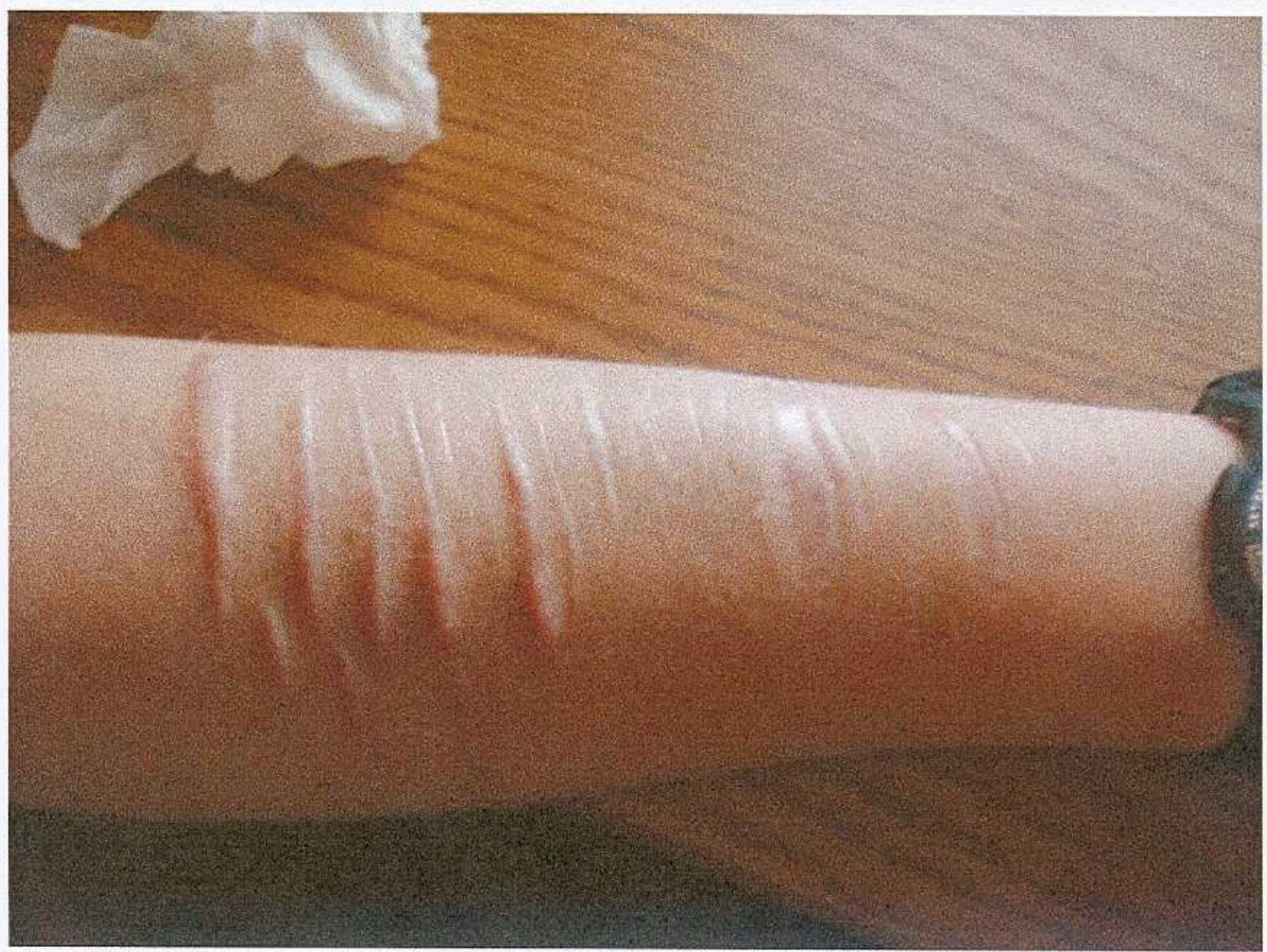

Fig. 5. 


\section{Notes}

${ }^{1}$ The paper is based on results and interpretations that grown out the research project The Semiotics of Pain - self inflicted pain as communication. The project is financed by the Swedish Research Council and is placed at Gender studies, a section of Global Political Studies, Malmö University in Sweden.

2 AR Favazza, Bodies under Siege, Self-mutilation and Body Modification in Culture and Psychiatry, The Johns Hopkins University Press, Baltimore and London, 1987/1996.

${ }^{3}$ Favazza study on self-mutilation and body-modification has become a standard work and his definition of self-injury as an act that doesn't express suicidal tendencies (which was earlier formulated by Menninger 1938) has been commonly accepted. An extensive body of academic work has been published on self-injury during the last decades. The main part of these has its origins in psychological, medical and sociological disciplines. Rarely, to my knowledge, you'll find research concerning cultural expressions connected to self-injury. There are of course some examples for instance Barbara Brickman's study on the construction of a prototypical, female self-injurer or the Swedish ethnologist Anna Johansson with her coming doctorial dissertation concerning web based biographical narratives from self-injurers.

4 Whitlock et. al., 'The Internet and Self-Injury: What Psychotherapists Should Know,' Journal of Clinical Psychology: In Session, Vol. 63 (11) 2007, p.1139.

${ }^{5}$ These parts of the study aren't presented in this paper.

${ }^{6}$ See e. g. AR Favazzas \& K Conterio, 'Female Habitual Self-Mutilators,' Acta Psychiatric Scandinavia, Vol. 79, 1989, p 286 or Socialstyrelsen [The National Board of Health and Welfare], Flickor som skadar sig själva, En kartläggning av problemets omfattning och karaktär. Article no. 2004-107-1, p. 14.

7 O Findahl \& S Zimic, Unga svenskar och Internet 2008. World Internet Institute, Hudiksvall, 2008, p. 7.

${ }^{8}$ The images are published with permission from the photographers (DC, Katie and MyLastKiss) if the anonymity could be guaranteed. Some of them were published on the website in question and others in different ways given to me. They are used here as typical examples of the images discussed in the text.

9 A Johansson, 'Rakbladsflikkor: Om kvinnlig självskada som identitet och symbolspråk'. Nätverket, no. 14, 2004(a), pp. 100-114. http://publications.uu.se/journals/1651-0593/natverket.htm, pp. 107-110.

${ }^{10} \mathrm{G}$ Kress \& $\mathrm{T}$ van Leeuwen, Reading Images, The Grammar of Visual Design, Second edition. Routledge, London \& New York, 1996/2006, pp.:160-163, 165166.

${ }^{11}$ Kress \& van Leeuwen, p. 165. 
${ }^{12}$ L Mulvey, 'Visual Pleasure and Narrative Cinema,' Visual and Other Pleasures, Indiana University Press, Bloomington and Indianapolis, 1989, pp. 19-20.

13 A Marner, Burkkänslan, surrealism i Christer Strömholms fotografi, en undersökning med semiotisk metod, diss. Institutionen för konstvetenskap; Institutionen för estetiska ämnen, Umeå universitet, 1999, p. 74.

14 G Pollock, 'Saknade kvinnor, Omprövning av de första tankarna om kvinnobilder', in Att tolka bilder, Bildtolkningens teori och praktik med exempel på tolkningar av bilder från 1850 till $i$ dag. Ed., Jan-Gunnar Sjölin, Studentlitteratur, Lund, 1993, p. 439.

15 See e. g. Favazza, p. 278.

${ }^{16}$ D Milia, Self-Mutilation and Art Therapy, Violent Creation. Jessica Kingsley Publishers, London and Philadelphia, 2000, p. 61.

${ }^{17}$ Ibid., p. 74.

${ }^{18}$ E Scarry, The Body in Pain, The Making and Unmaking of the World, Oxford University Press, New York \& Oxford, 1985, p. 4.

${ }^{19}$ In search of approaches that conquer the phallocentric ground for the formation of identity the literature historian Lilian Munk Rösing is suggesting that the skin should be the metaphor for sexual relations. Sexuality becomes more about the meeting of two persons through the skin then something centered on penetration, see LM Rösing, 'Hudens kön'. Divan No.1-2, 2001, pp. 20-34. She's deriving her approach from the French psychoanalyst Didier Anzieu's notion of The skin ego (1985).

\section{Bibliography}

Brickman, B., “Delicate' Cutters: Gendered Self-Mutilation and Attractive Flesh in Medical Discourse.' Body \& Society. Vol. 10, no. 4, 2004, pp. 87-111.

Favazza, A.R., Bodies under Siege, Self-mutilation and Body Modification in Culture and Psychiatry. The Johns Hopkins University Press, Baltimore and London, 1987/1996.

Favazzas, A R. \& Conterio K., 'Female Habitual Self-Mutilators.' Acta Psychiatric Scandinavia. Vol. 79, 1989, pp. 283-289.

Findahl, O. \& Zimic, S., Unga svenskar och Internet 2008 [Young Swedes and Internet 2008]. World Internet Institute, Hudiksvall, 2008. 
Johansson, A., 'Rakbladsflikkor: Om kvinnlig självskada som identitet och symbolspråk' [Razorblade Girls: About Female Self-injury as Identity and Symbolic Language]. Nätverket, no. 14, 2004(a), pp. 100-114. http://publications.uu.se/journals/1651-0593/natverket.htm.

Johansson, A., 'Ett vackert lidande' [A Beautiful Suffering]. Kulturella perspektiv. no. 4, 2004, pp. 33-41.

Kress, G \& van Leeuwen, T., Reading Images, The Grammar of Visual Design. Second edition. Routledge, London \& New York, 1996/2006.

Marner, A., Burkkänslan, surrealism $i$ Christer Strömholms fotografi, en undersökning med semiotisk metod [Canned Feeling-Surrealism in the Photography of Crister Strömholm-A Semiotic Inquiry]. diss. Institutionen för konstvetenskap; Institutionen för estetiska ämnen, Umeå universitet, 1999.

Menninger, K.A., Man Against Himself. Harcourt, Brace \& Co., New York, 1938.

Milia, D., Self-Mutilation and Art Therapy, Violent Creation. Jessica Kingsley Publishers, London and Philadelphia, 2000.

Mulvey, L., 'Visual Pleasure and Narrative Cinema.' Visual and Other Pleasures. Indiana University Press, Bloomington and Indianapolis, 1989, pp. 14-26. First published 1973.

Pollock, G., 'Saknade kvinnor, Omprövning av de första tankarna om kvinnobilder' [Missing Images: Rethinking Early Thoughts on Images of Women].' Att tolka bilder, Bildtolkningens teori och praktik med exempel på tolkningar av bilder från 1850 till $i$ dag. Ed., Jan-Gunnar Sjölin, Studentlitteratur, Lund, 1993, First published 1990.

Rösing, L.M., 'Hudens kön [The Sex of the Skin].' Divan. No.1-2, 2001, pp. 2034.

Scarry, E., The Body in Pain, The Making and Unmaking of the World. Oxford University Press, New York \& Oxford, 1985.

Socialstyrelsen, [The National Board of Health and Welfare], Flickor som skadar sig själva, En kartläggning av problemets omfattning och karaktär [Girls that Hurt Themselves: A Mapping of the Extent and Character of the Problem]. Article no. 2004-107-1. 
Whitlock, et. al., 'The Internet and Self-Injury: What Psychotherapists should Know.' Journal of Clinical Psychology: In Session, Vol. 63 (11) 2007, pp. 11351143.

Hans T. Sternudd $\mathrm{PhD}$, Swedish Art Historian working at Malmö and Växjö university, with research addresses performance/action art, gender, semiotics and visual culture. 